TEME, г. XLIV, бр. 3, јул - септембар 2020, стр. 913-928

\begin{tabular}{lr}
\hline \hline Оригинални научни рад & https://doi.org/10.22190/TEME181014062P \\
Примљено: 14.10 .2018$. & UDK 338.48:796.61(497.11Podunavlje)
\end{tabular}

Ревидирана верзија: 14. 12. 2019.

Одобрено за штампу: 1. 10. 2020.

\title{
LOCAL RESIDENTS' ATTITUDES TOWARDS CYCLING TOURISM IN THE UPPER DANUBE REGION (SERBIA)
}

\author{
Vanja Pavluković”, Bojana Nikić, Uglješa Stankov \\ University of Novi Sad, Faculty of Sciences, Novi Sad, Serbia \\ *vanja.dragicevic@dgt.uns.ac.rs
}

\begin{abstract}
Cycling tourism is an important and growing niche tourism market in Europe. It can contribute to the sustainable development and branding of the tourist destination, the preservation of natural and cultural heritage, the development of other forms of tourism, the creation of the tourist offers and active inclusion of the local community in development of tourism. Cycling tourism is recognized in the strategic documents of the Republic of Serbia as one of the key tourist products that should be developed in the selected tourist destinations. As local community has an important role in tourism development, in this paper, TIAS scale (Tourism Impact Attitude Scale) was used to examine the local residents' attitudes towards cycling tourism in the selected municipalities in the Upper Danube region through which Danube cycle route passes. It is the longest cycling corridor in Serbia, rich in natural and cultural heritage elements along its course, which is also part of one of the most popular European cycling routes, the EuroVelo 6. In addition, the effects of certain demographic variables on the residents' attitudes were examined. The results of the research indicate that cycling tourism is in the initial phase of tourism development in the studied area, and that local residents are aware of its possible positive impacts, therefore providing support for cycling tourism development. The results will be most valuable in assisting local governments, destination management organizations, tourism policy creators and tourism practitioners to understand the local residents' attitudes towards cycling tourism and to formulate strategies to effectively manage sustainable tourism development.
\end{abstract}

Key words: cycling tourism, Danube cycle route, local residents, TIAS.

\section{СТАВОВИ ЛОКАЛНОГ СТАНОВНИШТВА \\ О БИЦИКЛИСТИЧКОМ ТУРИЗМУ У ГОРЫЕМ ПОДУНАВЉУ (СРБИЈА)}

\section{Апстракт}

Бициклистички туризам је селективни облик туризма, који има све значајнију улогу на европском туристичком тржишту. Значајно може допринети одрживом развоју и брендирању туристичке дестинације, очувању природног и културног наслеђа, осмишљавању туристичке понуде, развоју других облика туризма и може под- 
стаћи активну укљученост локалне заједнице у развој туризма. Бициклистички туризам је у стратешким и планским документима Републике Србије препознат као један од кључних туристичких производа које треба развијати у одабраним туристичким дестинацијама. Како локална заједница има значајну улогу у развоју туризма, у раду су применом ТИАС скале (енгл. Tourism Impact Attitude Scale) испитивани ставови локалног становништва о бициклистичком туризму у одабраним општинама у Горњем Подунављу, кроз које пролази Дунавска бициклистичка рута. То је најдужа бициклистичка траса у Србији, која представља и део Еуровела 6, једног од најатрактивнијих европских бициклистичких коридора. Такође, испитиван је и утицај одређених социо-демографских карактеристика на ставове локалног становништва. Резултати истраживања указују на то да је бициклистички туризам тек у почетној фази развоја, те да испитаници препознају могуће позитивне ефекте од развоја овог облика туризма и да му стога пружају подршку. Резултати овог истраживања могу бити од користи локалним властима, туристичким организацијама и свим другим субјектима који се баве развојем туризма на различитим нивоима.

Кључне речи: бициклистички туризам, Дунавска бициклистичка рута, локално становништво, TIAS.

\section{INTRODUCTION}

Cycling is an important mode of non-motorized transport of local residents in some countries, such as China where as much as $65 \%$ of trips are done by bicycle. On the contrary, in the United States, the bicycle is used for the same purpose in only 3\% of the cases. In Europe, the bicycle is widely used in countries such as Denmark, Germany and Netherlands (Karanikola, Panagopoulos, Tampakis, \& Tsantopoulos, 2018). In the context of tourism, cycling represents an activity on a holiday or the type of active holiday. In fact, cycling tourism is a travel experience that focuses on the bicycle as the primary mode of transport between destinations in a small group of people or even individually for leisure purposes (Millington, 2013). The bicycle in not just a means of transport, it is an integral part of the tourist experience (Lumsdon, 2000). Cycling tourism can be easily combined with other types of special interest tourism, such as cultural, gastronomy, wine, rural, religious tourism, etc. It can contribute to the sustainable development and branding of the tourist destination, the preservation of natural and cultural heritage, the development of other forms of tourism, the creation of the tourist offer and active inclusion of the local community in tourism development (Karanikola et al., 2018; Manton, Hynes, \& Clifford, 2016).

For the development of cycle tourism in a destination it is necessary to create a network of cycling routes, linear routes which follow roads, railways or waterways (e.g. Danube cycle route along the Danube) or circle routes with natural and cultural heritage elements along the course. Cycling routes represent tourist attractions by themselves, because, beside infrastructural elements, they encompass natural and cultural heritage of the area they pass through, or they have a thematic character (e.g. cycling 
route connecting wineries and wine cellars in wine region). The best example is the European cycle route network - EuroVelo, a network of 15 long-distance routes managed by the European Cyclists' Federation which is being developed in different countries by a wide range of partners (European Parliament, Directorate General for Internal Policies Policy Department B: Structural and Cohesion Policies, 2012). This network encompasses a variety of routes such as wine routes, Atlantic coast routes, routes connecting European capitals, or cultural heritage from different periods of history. For example, the European Route of Brick Gothic is a cycling route which connects cities and towns in the Baltic Sea region that share a common architectural tradition developed based primarily on the use of red brick and distinctive gothic designs. EuroVelo 3, also known as the Pilgrim's route, connects Europe's most impressive religious buildings, including the impressive cathedrals of Cologne, Aachen and Santiago de Compostela. EuroVelo 13 - Iron Curtain Trail passes through 20 different countries, including 14 members of the EU, as well as Serbia. It traverses many national parks with interesting flora and fauna and unique landscapes. The path also connects many buildings, monuments, museums and attractions that remind us of the history of the division of Europe, and its ending via a peaceful 'velvet' revolution in Eastern Europe. In 2005, the European Parliament recognized the Iron Curtain Trail as a model project for sustainable tourism and called upon the Member States for support (EuroVelo). With continuous signage on Eurovelo routes, tourists are directed towards specific destinations or must-see natural and cultural attractions. All routes offer high standards of design, signage and promotion throughout Europe, as well as branding and interpretation of destinations and cultural and natural heritage along the routes (Lumsdon \& Tolley, 2004).

The benefits for destination from developing cycling tourism can be the following: equal or greater tourism expenditure by cycling tourists compared to other tourist segments; generating the demand and developing the supply for specific products and services in the destination; the use of local service providers, small and medium entrepreneurship development and the increase of financial influx to the local economy; the minimal environmental impact on the destination compared to the other modes of transport and other forms of tourism; the revitalization and use of existing and insufficiently used, run-down or outdated infrastructure; improving the destination image, tourist offer and attracting new or different visitors; increasing the activity of the local residents and other benefits for the community that come from a more active lifestyle (Mrnjavac, Kovačić, \& Topolšek, 2014; Sustrans, 1999).

Most studies indicate that cycle tourists are motivated to take cycling holidays comprised of a mix of elements, but especially the opportunity to relax from every-day life, being close to nature, the ability to explore other places/cultures, etc. (Lumsdon \& Smith, 1997; Lumsdon, 
2000). This segment of tourists prefers destinations which can provide adequate infrastructure, traffic safety (low traffic density), signposting on cycle routes that makes it easy to navigate, but also information about natural and cultural heritage close to the route, accommodation/catering service providers (Lumsdon \& Tolley, 2004), as well as other cyclist-friendly service providers, which all further contribute to small entrepreneurship development and especially in neglected rural areas along the cycling routes and in areas which are not the typical tourist honey-pot sites and would not be able to attract visitor spending otherwise.

Cycle tourism is not recorded in Eurostat tourism statistics, nor is it featured in other general reviews of domestic or international tourism. Therefore, there is no clear overview of trends. However, the EuroVelo study 2012 indicates that cycle tourism brings major benefits to destinations from direct tourist spending, specifically in those localities which currently do not enjoy mainstream tourism development (European Parliament, Directorate General for Internal Policies Policy Department B: Structural and Cohesion Policies, 2012). In addition, socio-cultural impacts of cycling tourism on local communities should not be neglected especially since cycle tourists look for direct contact with local residents. Many studies indicate that local communities support development of cycling routes and other greenways for recreational use and tourism since it improves local businesses, community involvement and pride in local heritage with greenway routes (Bennett, Tranter, \& Blaney, 2003; Bowker, Bergstrom, \& Gill, 2007; European Greenways Association, 2004), which further contribute to the quality of life of local residents (Schafer, Bong, \& Turner, 2000).

The local community is one of the key stakeholders in tourism development and its attitudes towards tourism impacts should be acknowledged in order to provide sustainable tourism development. Therefore, there are many studies, which refer to the community role and support in tourism development and the residents' perception on the impact of tourism. One of the first standardized instruments for measuring residents' attitudes towards tourism development is the Tourism Impact Attitude Scale - TIAS, developed by Lankford and Howard (1994). After the scale was tested in the United States, the authors called for additional testing in different settings. In response to this call, the scale was widely used in tourism related research in other countries, with certain modifications depending on the type of destination and form of tourism (Bachleitnera \& Zins, 1999; Chen \& Hsu, 2001; Harrill \& Potts, 2003; Petrović, Blešić, Ivolga, \& Vujko, 2016; Shariff, 2002; Vesey \& Dimanche, 2001; Wang \& Pfister, 2008). The original TIAS consists of 27 attitudes/variables used to measure the local residents' perception of tourism development. The attitudes refer to infrastructure, public services, recreation, employment 
opportunities, income generation, role of local resident' in tourism planning and other impacts of tourism development on local community.

Cycling tourism is recognized in the strategic documents of the Republic of Serbia as one of the key tourist products that should be developed in the selected tourist destinations, specifically the Danube region (Ministry of Trade, Tourism, and Telecommunications of the Republic of Serbia, 2016). The fact is that three out of 15 international cycling routes of the EuroVelo network are passing through Serbia: EuroVelo 6, EuroVelo 11 and EuroVelo 13. EuroVelo 6 is one of the most popular cycling routes in Europe, connecting the west and east of Europe, from the Atlantic to the Black sea. This route follows the Loire, the Rhine and the Danube. The EuroVelo 6 section in Serbia follows the Danube and is known as the Danube cycle route, the longest cycling corridor in Serbia. It is the result of the international project Donauradweg (Danube Bicycle Route) aimed to trace the cycling route along the Danube downstream from Austria and Slovakia, and to design the cycling maps. The project was conducted in Hungary, Croatia, Serbia, Romania and Bulgaria. The route in Serbia was entirely realized in 2007 and is known for its outstanding natural and cultural attractions (EuroVelo).

However, according to the Tourism development strategy of the Republic of Serbia 2016-2025 no progress was made and no significant investments were generated for the improvement of the quality of the tourist products of special interest such as cultural, cycling, wine and culinary and gastronomic routes (Ministry of Trade, Tourism, and Telecommunications of the Republic of Serbia, 2016, p. 14). In addition, there is a lack of academic research on the topic of cycling tourism in Serbia, and specifically on the residents' attitudes towards cycling tourism development. Previous studies mostly focus on cycling tourists, the establishment of cycling routes in Serbia and the supply side (Bogdanović, Basarić, Ruškić, \& Garunović, 2016; Vujko, Plavša, \& Ostojić, 2013; Vujko \& Gajić, 2014).

As local community has an important role in tourism development and long-term planning, the aim of this paper is to examine the local residents' attitudes towards cycling tourism in the selected municipalities in the Upper Danube region through which Danube cycle route passes utilizing the TIAS scale. This study is significant as it utilizes TIAS in a novel research setting of cycling tourism (in previous studies the scale was mostly used in the context of rural tourism). In addition, the effects of certain demographic variables on the residents' attitudes were examined. Specifically, this study seeks to answer the following research questions:

(1) What are the attitudes of the local residents in the selected municipalities in the Upper Danube toward cycling tourism development in this region?

(2) Do local residents support cycling tourism development in their community? 
(3) Are there statistically significant differences in the local residents' attitudes towards cycling tourism development between respondents of different gender, age, education, and monthly income? discussion:

The following hypotheses are proposed according to the prior

Hypothesis 1 (H1): Local residents have a positive and supportive attitude towards cycling tourism development.

Hypothesis 2 (H2): Socio-demographic characteristics of local residents influence their attitudes towards cycling tourism development.

Hypothesis 2a: There are statistically significant differences in the local residents' attitudes towards cycling tourism development between respondents of different gender.

Hypothesis 2b: There are statistically significant differences in local residents' attitudes towards cycling tourism development between respondents of different age.

Hypothesis 2c: There are statistically significant differences in local residents' attitudes towards cycling tourism development between respondents of different educational level.

Hypothesis 2d: There are statistically significant differences in local residents' attitudes towards cycling tourism development between respondents of different monthly income.

\section{METHODOLOGY}

To achieve the objective of the study, a two-step procedure was conducted. First of all, in order to adapt the original TIAS to research setting of cycling tourism, three academics from Serbia who have research experience in tourism and specifically niche tourism were asked to discuss the TIAS. Based on this discussion, the original scale was refined and 22 out of 27 items from TIAS were adapted to this research. Therefore, the final scale used in this survey consists of 22 items with good internal consistency $(\alpha=0.83)$.

Second of all, by using the modified scale, the main survey was conducted among local residents of the selected municipalities in the Upper Danube through which the Danube cycle route passes: Apatin, Sombor and Bačka Palanka, in the summer months (June-September 2016) when the concentration of cycling tourists on the route is the highest.

The questionnaire used was composed of three sections. The first part included background information on the participants (gender, age, education, place of residence, length of residency, occupancy, monthly income). The second part consisted of three questions which refer to the residents' familiarity with the fact that the Danube cycle route - EuroVelo 6 passes through their municipality, providing services to cycling tourists or not, and giving support to cycling tourism development or not. In the 
third part of the questionnaire, the residents were asked to evaluate 22 items - their attitudes towards cycling tourism development in their community using a five-point Likert scale ranging from 1 (strongly disagree) to 5 (strongly agree). A face-to-face survey was conducted with 109 respondents. Their socio-demographic characteristics are presented in detail in Table 1. The data was processed with the statistical package SPSS 20.

Table 1. Socio-demographic characteristics of the respondents

\begin{tabular}{|c|c|c|}
\hline Characteristics & $\mathrm{f}$ & $\%$ \\
\hline \multicolumn{3}{|l|}{ Gender } \\
\hline Male & 46 & 42 \\
\hline Female & 63 & 58 \\
\hline \multicolumn{3}{|l|}{ Age $(\mathrm{N}=109)$} \\
\hline$\leq 20$ & 6 & 5.5 \\
\hline $21-40$ & 57 & 52.3 \\
\hline $41-60$ & 39 & 35.8 \\
\hline$\geq 60$ & 7 & 6.4 \\
\hline \multicolumn{3}{|l|}{ Place of residence } \\
\hline Apatin & 28 & 25.6 \\
\hline Bačka Palanka & 32 & 29.4 \\
\hline Sombor & 49 & 45.0 \\
\hline \multicolumn{3}{|c|}{ Years of residence in the municipality } \\
\hline$\leq 10$ & 4 & 4 \\
\hline $11-20$ & 15 & 14 \\
\hline $21-30$ & 46 & 42 \\
\hline $31-40$ & 11 & 10 \\
\hline$\geq 40$ & 33 & 30 \\
\hline \multicolumn{3}{|l|}{ Education } \\
\hline High school & 76 & 69.7 \\
\hline Faculty & 33 & 33.3 \\
\hline \multicolumn{3}{|l|}{ Occupation } \\
\hline Student & 19 & 17 \\
\hline Employed & 38 & 35 \\
\hline Seasonal employment & 17 & 16 \\
\hline Retiree & 8 & 7 \\
\hline Unemployed & 27 & 25 \\
\hline \multicolumn{3}{|l|}{ Monthly income in $€$} \\
\hline$\leq 200$ & 26 & 24 \\
\hline $201-400$ & 29 & 27 \\
\hline 401 and more & 20 & 18 \\
\hline No income & 34 & 31 \\
\hline
\end{tabular}




\section{RESULTS AND DISCUSSION}

Results of the research show that $66.1 \%$ of the respondents are familiar with the fact that the Danube cycle route - EuroVelo 6 passes through their place of residence. The majority of the respondents (88.1\%) support cycling tourism development in their municipality mostly because they enjoy cycling, they see cycling tourism as an opportunity for the local economy revival, for improving employability for local residents and the infrastructure development. Only one respondent does not support cycling tourism development whereas 12 neither agree nor disagree. A small percentage of the respondents $(9.2 \%)$ provide services to cycling tourists and those are mostly accommodation, food, bicycle repair and tour guide services.

Surprisingly, more than $40 \%$ of the respondents consider that cycling tourism development did not contribute to more recreational opportunities in their community, while 33\% are undecided regarding this item. A high percentage of the respondents (more than 70\%) disagree with the statement that the quality of public service in their community has been improved thanks to cycling tourism development. On a positive note, local residents (92.6\%) do not think that the development of this type of tourism has influenced the rise of crime rate in their community. Almost half of the respondents state that cycling tourism does not play an important role in the local economy, while $32 \%$ are uncertain regarding this topic, which indicates that cycling tourism is in the initial phase of development or local residents are not adequately informed about it. Over $60 \%$ of the respondents disagree with the statement that the number of shops, bike repair shops and other service providers has increased as a result of cycling tourism development. In addition, they do not think that roads, pavements and cycling paths in their community are improved thanks to cycling tourism development, which points to none or very small investments in the infrastructure for cycling tourists, as well as for local residents. More than $90 \%$ of the respondents do not have income from cycling tourism, which implies that this form of tourism is still underdeveloped, and the involvement of the local community in its development is very low. On the other hand, almost $80 \%$ of the respondents consider that the local authorities and community should actively support cycling tourism development, and the majority supports the building of new or adaptation of existing tourist facilities which could attract a large number of visitors and cycling tourists.

Local residents do not notice negative impacts of cycling tourism towards their environment, which was expected considering their above discussed answers and the fact that this type of tourism is still underestimated in the economy of the study area. In addition, less than $40 \%$ of the respondents are interested in providing services to cycling tourists. It is our assumption that more local residents would provide cycling friendly services if there existed appropriate incentives for future 
Table 2. Mean values and distribution of the respondents' answers

\begin{tabular}{|c|c|c|c|c|c|c|}
\hline \multirow[t]{2}{*}{ Items } & \multirow[t]{2}{*}{ M } & \multicolumn{5}{|c|}{$\begin{array}{l}\text { Respondents' answers } \\
\text { in \% }\end{array}$} \\
\hline & & 1 & 2 & 3 & 4 & 5 \\
\hline $\begin{array}{l}\text { The Danube cycle route and cycling tourism } \\
\text { development contributed to more recreational } \\
\text { opportunities in my community. }\end{array}$ & 2.78 & 24.8 & 16.5 & 33.0 & 7.4 & 18.3 \\
\hline $\begin{array}{l}\text { The quality of public services in my community has been } \\
\text { improved thanks to cycling tourism development. }\end{array}$ & 1.73 & 58.7 & 14.7 & 23.9 & 0.9 & 1.8 \\
\hline $\begin{array}{l}\text { Cycling tourism has influenced the rise of crime rate } \\
\text { in my community. }\end{array}$ & 1.22 & 85.3 & 7.4 & 6.4 & $\begin{array}{l}+0.9 \\
\end{array}$ & 0.0 \\
\hline $\begin{array}{l}\text { Cycling tourism plays an important role in the } \\
\text { economy of my municipality. }\end{array}$ & 2.48 & 30.3 & 18.3 & 32.1 & 11.0 & 8.3 \\
\hline $\begin{array}{l}\text { In my place of residence, the number of shops, bike } \\
\text { repair shops and other service providers has risen as a } \\
\text { result of cycling tourism development. }\end{array}$ & 1.70 & 59.6 & 17.4 & 17.4 & 3.7 & 1.8 \\
\hline Cycling tourism provides extra income for my family. & 1.22 & 91.7 & 1.9 & 1.8 & 0.9 & 3.7 \\
\hline $\begin{array}{l}\text { The community should stimulate a more intensive } \\
\text { building of facilities for cycling tourism. }\end{array}$ & 3.95 & 2.8 & 6. & 29.3 & 15.6 & 45.9 \\
\hline $\begin{array}{l}\text { The jobs provided by cycling tourism development are } \\
\text { very attractive. }\end{array}$ & 3.25 & 7.3 & 13 & 45.9 & 12.8 & 20.2 \\
\hline $\begin{array}{l}\text { Prices of products and services increased in my } \\
\text { community due to cycling tourism development. }\end{array}$ & 1.64 & 62. & 2. & 11.0 & 0.9 & 4.6 \\
\hline $\begin{array}{l}\text { My community has better roads, pavements and } \\
\text { cycling paths thanks to cycling tourism development. }\end{array}$ & 2.11 & 46.8 & 11.9 & 28.4 & 10.1 & 2.8 \\
\hline $\begin{array}{l}\text { Cycling tourism development in my community will } \\
\text { provide more opportunities for employment of local } \\
\text { population. }\end{array}$ & 3.12 & 13.8 & 16.5 & 33.9 & 14 & 21.1 \\
\hline $\begin{array}{l}\text { In my community, cycling tourism development } \\
\text { should be actively supported. }\end{array}$ & 4.30 & 0.9 & 2.8 & 19.2 & 20.2 & 56.9 \\
\hline $\begin{array}{l}\text { I support building of new or adaptation of existing } \\
\text { tourist facilities which could attract a large number of } \\
\text { visitors and cycling tourists in my community. }\end{array}$ & 4.62 & 0.9 & 0.0 & 8.3 & 18.3 & 72.5 \\
\hline $\begin{array}{l}\text { Cycling tourists behave inappropriately towards the } \\
\text { environment (throw waste, make noise, damage plants } \\
\text { and disturb animals, etc.). }\end{array}$ & 1.48 & 73. & & 11.9 & 3.7 & 0.9 \\
\hline $\begin{array}{l}\text { I believe the increase in the number of cycling tourists } \\
\text { will not have negative impact on the local environment. }\end{array}$ & 3.74 & 11.0 & 4.6 & 22.0 & 23.9 & 38.5 \\
\hline $\begin{array}{l}\text { In my community the amount of litter has increased } \\
\text { due to cycling tourism development. }\end{array}$ & 1.44 & 72.5 & 11.0 & 16.5 & 0.0 & 0.0 \\
\hline $\begin{array}{l}\text { In the future, I would like to provide services to } \\
\text { cycling tourists. }\end{array}$ & 3.06 & 25.7 & 6. & 29.4 & 12 & 25.7 \\
\hline I made friends with cycling tourists. & 1.89 & 58.7 & 12.8 & 13.8 & 9.2 & 5.5 \\
\hline $\begin{array}{l}\text { I communicate with cycling tourist passing through } \\
\text { my community. }\end{array}$ & 2.4 & 44.0 & 12.0 & 18.3 & 37. & 18.3 \\
\hline $\begin{array}{l}\text { I am able to influence the decision-making on the } \\
\text { cycling tourism development in my community }\end{array}$ & 1.45 & 78.0 & 2.8 & 16.5 & 1.8 & 0.9 \\
\hline $\begin{array}{l}\text { Cycling tourism development can only have positive } \\
\text { impact on my life. }\end{array}$ & 3.57 & 6.4 & 7.4 & 39.4 & +10.5 & 30.3 \\
\hline $\begin{array}{l}\text { My community has natural and cultural resources to } \\
\text { become an attractive cycling tourist destination. }\end{array}$ & 4.05 & 0.0 & 2.8 & 27.5 & 31 & 38.5 \\
\hline
\end{tabular}

$\mathrm{M}$ - mean value; 1 - strongly disagree; 2 - disagree;

3 - neither agree nor disagree; 4 - agree; 5 - strongly agree 
entrepreneurs from local or state authorities and if they were properly informed and educated on cycling tourism market and all the benefits it could bring to the community. Moreover, about $80 \%$ of the respondents state that they are not able to influence decision making on the cycling tourism development in their community. Therefore, it is necessary to organize suitable education through workshops, seminars, etc. for local residents regarding the benefits and positive impacts of cycling tourism development towards the local community. The local community must be informed about all the potential benefits and costs of this type of tourism and must be involved in the planning and development of cycling tourism. On a positive note, almost $70 \%$ of the respondents believe their community has natural and cultural resources to become an attractive cycling tourist destination. Therefore, based on the results of this study, we can conclude that the respondents have a positive attitude and are supportive towards future cycling development in their community ( $\mathrm{H} 1$ confirmed), but, at this moment, cycling tourism is underdeveloped or in its initial phase of development in the studied area, meaning the potentials of the Danube cycle route are not sufficiently used.

In order to examine if there are differences in the residents' attitudes towards cycling tourism in the Upper Danube area through which the Danube cycle route passes, regarding their gender, age and education level, MannWhitney U Test is used.

The results show that there is no statistically significant difference in attitudes of female and male respondents towards cycling tourism $(\mathrm{H} 2 \mathrm{a}$ rejected). Also, no statistically significant difference is determined in attitudes across the age of the respondents ( $\mathrm{H} 2 \mathrm{~b}$ rejected), but there are significant differences in several attitudes (see Table 3) across the educational level of the respondents. However, the value of the effect size is small $(r<0.3)$, thus, these differences are not essential $(\mathrm{H} 2 \mathrm{c}$ rejected).

Table 3. Results of Mann-Whitney U Test used to assess for significant differences in respondents' attitudes regarding their education

\begin{tabular}{|c|c|c|c|c|c|c|c|c|}
\hline Items & Education & $\mathrm{N}$ & $\mathrm{Mr}$ & $\mathrm{Md}$ & $\mathrm{U}$ & $\mathrm{p}$ & $\mathrm{Z}$ & $\mathrm{r}$ \\
\hline \multirow{2}{*}{$\begin{array}{l}\text { Cycling tourism plays an } \\
\text { important role in the economy } \\
\text { of my municipality. }\end{array}$} & High school & 76 & 50.90 & 2 & \multirow{2}{*}{\multicolumn{2}{|c|}{942.50 .033}} & \multirow{2}{*}{-2.129} & \multirow{2}{*}{0.20} \\
\hline & Faculty & 33 & 64.44 & 3 & & & & \\
\hline \multirow{2}{*}{$\begin{array}{l}\text { Cycling tourism provides } \\
\text { extra income for my family. }\end{array}$} & High school & 76 & 52.62 & 1 & \multirow{2}{*}{\multicolumn{2}{|c|}{10730.012}} & \multirow{2}{*}{-2.501} & \multirow{2}{*}{0.24} \\
\hline & Faculty & 33 & 60.48 & 1 & & & & \\
\hline \multirow{2}{*}{$\begin{array}{l}\text { The jobs provided by cycling } \\
\text { tourism development are very } \\
\text { attractive. }\end{array}$} & High school & 76 & 51.28 & 3 & \multirow{2}{*}{\multicolumn{2}{|c|}{971.50 .048}} & \multirow{2}{*}{-1.975} & \multirow{2}{*}{0.19} \\
\hline & Faculty & 33 & 63.56 & 3 & & & & \\
\hline \multirow{2}{*}{$\begin{array}{l}\text { Cycling tourism development } \\
\text { can have only positive impact } \\
\text { on my life. }\end{array}$} & High school & 76 & 51.26 & 3 & \multirow{2}{*}{\multicolumn{2}{|c|}{9700.049}} & \multirow{2}{*}{-1.968} & \multirow{2}{*}{0.19} \\
\hline & Faculty & 33 & 63.61 & 4 & & & & \\
\hline
\end{tabular}

$\mathrm{N}$ - number of respondents, $\mathrm{Mr}$ - mean rank, Md - Median, $\mathrm{U}$ - value of Man Whitney U test, $\mathrm{p}$ - level of significance, $\mathrm{r}$ - effect size 
Conducting Kruskal-Wallis Test, statistically significant difference is noticed in four out of 22 residents' attitudes towards cycling tourism (see Table 4) across monthly income (H2d confirmed). The respondents with the highest monthly income show higher level of the agreement, compared to the respondents with lower monthly income, with the statements that cycling tourism plays an important role in the local economy, it provides extra income for their family and the infrastructure is improved thanks to cycling tourism development. The respondents with no income especially notice the increase in prices of products and services due to cycling tourism development, which we assume is not the effect of cycling tourism but of low socioeconomic status of this group of the respondents.

Table 4. Results of Kruskal-Wallis Test used to assess for significant differences in respondents' attitudes regarding their monthly income

\begin{tabular}{lcccccc}
\hline Items & $\begin{array}{c}\text { Monthly } \\
\text { income }\end{array}$ & Mr & Md & $\chi^{2}$ & $\mathrm{p}$ \\
\hline Cycling tourism plays an important & $\leq 200$ & 52.06 & 2 & & \\
role in the economy of my & $201-400$ & 43.83 & 1 & 9.542 & 0.023 \\
municipality. & 401 and more & 70.48 & 3 & & \\
\hline & No income & 57.68 & 3 & & \\
Cycling tourism provides extra & $\leq 200$ & 52.54 & 1 & & \\
income for my family. & $201-400$ & 52.47 & 1 & 9.463 & 0.024 \\
& 401 and more & 64.33 & 1 & & \\
\hline Prices of products and services & No income & 53.56 & 1 & & \\
increased in my community due to & $\leq 200$ & 41.50 & 1 & & \\
cycling tourism development. & 401 and more & 59.68 & 1 & 1 & 15.884 & 0.001 \\
\hline My community has better roads, & No income & 67.81 & 2 & & \\
pavements and cycling paths thanks & $\leq 200$ & 43.38 & 1 & & \\
to cycling tourism development. & 201-400 & 46.10 & 1 & 13.517 & 0.004 \\
\hline
\end{tabular}

$\mathrm{Md}$ - median, $\mathrm{Mr}$ - mean rank, $\chi^{2}$ - chi-square value, $\mathrm{p}$ - level of significance

\section{CONCLUSION}

The market for cycle tourism as a form of active holiday is constantly increasing in Europe, and the Danube cycle route, as part of EuroVelo 6, represents one of the most attractive European corridors for cycling tourists. However, it is important to note that the growth of cycle tourism, both in terms of provision and market demand, is uneven across the Danube cycle route. While Austria is by far the most important destination on Danube for tour operators according to EuroVelo study 2012, Serbia is lagging behind in cycling tourism development although its potential is immense. In Serbian tourism strategic documents, the 
development of cycling tourism in the Danube region is seen as an opportunity for the improvement of tourism offer of Serbia, as well as an opportunity for the revitalization of the rural settlements through which the Danube cycle route passes.

In cooperation with the European Cyclists' Federation, the European cycle route network and former German Technical Cooperation Agency (GTZ) ${ }^{1}$, cycling experts from Serbia together with those from Hungary, Croatia, Romania and Bulgaria have been working on developing a cycle route along the Danube since 2003. As a result of this project, in 2007, the Danube cycle route as part of EuroVelo 6 was established in Serbia and the sign post system was installed with the aim to provide cyclists following the Danube all the information they require. Also, printed maps as well as websites on cycling the Danube are produced and different promotion activities are carried out (National Tourism Organization of Serbia). It is thanks to this project that Serbia is on the European cycling tourists map and tour operators specialized for cycling holidays show interest in the Serbian section of the Danube.

In order to assess the residents' attitudes toward cycling tourism on the Danube cycle route in Serbia, the present study was conducted in the Upper Danube region, one of the four tourist destinations on Danube in Serbia according to the Tourism development strategy of the Republic of Serbia 2016-2025. This study is the first phase of the project, which includes research among the local residents in other municipalities along the whole Danube cycling route in Serbia (following studies will be conducted in the Central Danube region, the City of Belgrade with Novi Sad and the Lower Danube region).

The results of this research indicate that cycling tourism is in the initial phase of tourism development in this area. This is in line with previous research by Vujko and Gajić (2014) on the opportunities for tourism development and cooperation in the region by improving the quality of tourism services on the Danube cycle route. Local residents are aware of the possible positive impacts of cycling tourism development; therefore, they give support to it (H1 confirmed), which is in line with general tourism literature. No statistically significant differences were found in the residents' attitudes across their gender, age and educational level ( $\mathrm{H} 2$ rejected). The results will be most valuable in assisting local governments, destination management organizations, tourism policy creators and tourism practitioners to understand the local residents'

\footnotetext{
${ }^{1}$ As of 1 January 2011, the Deutsche Gesellschaft für Technische Zusammenarbeit $\mathrm{GmbH}$ (GTZ) has ceased to exist. It has been merged with the German Development Service (DED) and InWEnt (Capacity Building International, Germany) to become the Deutsche Gesellschaft für Internationale Zusammenarbeit (GIZ) (German Federal Ministry for Economic Cooperation and Development).
} 
attitudes towards cycling tourism and to formulate strategies to manage effectively sustainable tourism development. Tourism planners need to be aware of the need to conserve natural and cultural assets on the route, as well as to enhance community skills and capabilities related to cycling tourism. In addition, local community must be actively involved in activities related to cycling tourism development and directly benefit from it.

As local residents have direct contact with tourists, which can affect the tourists' experience of a destination, it is necessary to inform and educate the local community on the opportunities and benefits, as well as costs, of cycling tourism. Furthermore, the development of small and medium entrepreneurs in local community should be stimulated in order to provide cycle friendly services along the route. There are numerous examples of good practices from European countries where local and national authorities have been using different incentive measures in order to stimulate active involvement of the local community in cycling tourism development and the creation of the tourist offer.

Future research will be conducted in other municipalities along the Danube cycle route in Serbia in order to evaluate the residents' perception of cycling tourism development. Also, similar research among local residents should be conducted in other countries through which the Danube cycle route and EuroVelo 6 pass, as these countries differ in their level of economic and tourism development and there are differences in cultural and geographic contexts. In addition, as the local community's perceptions of tourism impacts are not static and destination and the level of tourism development change over time, research similar to the present study should be conducted on a regular basis.

\section{REFERENCES}

Bachleitner, R., \& Zins, A. H. (1999). Cultural tourism in rural communities: The residents' perspective. Journal of business research, 44(3), 199-209. doi: 10.1016/S0148-2963(97)00201-4

Bennett, R. M., Tranter, R. B., \& Blaney, R. J. P. (2003). The value of countryside access: a contingent valuation survey of visitors to the Ridgeway National Trail in the UK. Journal of Environmental Planning \& Management, 46(1), 659-671. doi: 10.1080/0964056032000138427.

Bogdanović, V., Basarić, V., Ruškić, N., \& Garunović, N. (2016). Study of the establishment of the regional cycling route Srem. Transportation research procedia $14,2334-2343$.

Bowker, J.M., Bergstrom, J.C., \& Gill, J. (2007). Estimating the economic value \& impacts of recreational trails: a case study of the Virginia Creeper Rail Trail. Tourism Economics 13(2), 241-260. doi: 10.5367/000000007780823203.

Chen, J. S., \& Hsu, C. HC. (2001). Developing \& validating a riverboat gaming impact scale. Annals of Tourism Research, 28(2), 459-476. doi: 10.1016/S0160-7383(00) 00059-1.

European Greenways Association. (2004). The European Greenways good practice guide. Namur: EGA. 
European Parliament, Directorate General for Internal Policies Policy Department B: Structural \& Cohesion Policies. (2012). The European cycle route network Eurovelo - Challenges \& Opportunities for Sustainable Tourism Study. Brussels: European Parliament.

EuroVelo, the European cycle route network. Retrieved July 13, 2018. from www.eurovelo.com.

German Federal Ministry for Economic Cooperation and Development. Retrieved January 10, 2020 from https:/www.bmz.de/en/ministry/approaches/bilateral_development_ cooperation/players/selection/gtz/index.html.

Harrill, R., \& Potts, T. D. (2003). Tourism planning in historic districts: Attitudes toward tourism development in Charleston. Journal of the American Planning Association, 69(3), 233-244. doi: 10.1080/01944360308978017.

Karanikola, P., Panagopoulos, T., Tampakis, S., \& Tsantopoulos, G. (2018). Cycling as a smart and green mode of transport in small touristic cities. Sustainability, 10(1), 268. doi: 10.3390/su10010268

Lankford, S. V., \& Howard, D.R. (1994). Developing a tourism impact attitude scale. Annals of tourism research, 21(1), 121-139. doi: 10.1016/0160-7383(94)90008-6.

Lumsdon, L., \& Smith, M.W. (1997). Developing the potential of recreational cycling in the Peak National Park. In: 10th International bicycle planning conference, 15-19 September 1997 (511-514). Barcelona, Spain.

Lumsdon, L. (2000). Investigating the needs of the recreational cyclist: The experience of the Peak District National Park. Town Planning Review, 71(3), 379-389. doi: 10.3828/tpr.71.4.j0gp6103v33p4j22.

Lumsdon, L., \& Tolley, R. (2004). Non-Motorised Transport \& Tourism: A Case Study Cycle Tourism. In: L. Lumsdon \& S.J. Page (Ed.), Tourism \& Transport Issues \& Agenda for the New Millennium, (pp. 147-156). London: Elsevier.

Manton, R., Hynes, S., \& Clifford, E. (2016). Greenways as a tourism resource: a study of user spending and value. Tourism Planning \& Development, 13(4), 427-448.

Millington, K. (2013). Cycling in Scandinavia - September 2013. Travel \& Tourism Analyst 16.

Mrnjavac, E., Kovačić, N., \& Topolšek, D. (2014). The logistic product of bicycle destinations. Tourism and hospitality management, 20(2), 171-184.

Ministry of Trade, Tourism, and Telecommunications of the Republic of Serbia (2016). Tourism development strategy of the Republic of Serbia 2016-2025. Belgrade.

National Tourism Organization of Serbia, Retrieved January 10, 2020 from http:/www.serbia.travel/useful-info/arrival/bicycle.2055.html.

Petrović, M.D., Blešić, I., Ivolga, A., \& Vujko, A. (2016). Agritourism impact toward locals' attitudes - an evidence from Vojvodina Province (Serbia). Journal of the Geographical Institute Jovan Cvijic, SASA, 66(1), 105-123.

Schafer, C.S., Bong, K.L., \& Turner, S. (2000). The tale of three greenway trails: user perceptions related to quality of life. Journal of Landscape \& Urban Planning, 49, 163-178. doi: 10.1016/S0169-2046(00)00057-8.

Shariff, N.M. (2002). Developing a scale to measure resident attitudes toward impacts of tourism in Langkawi (PhD Thesis). Malaysia: University of Strathclyde.

Sustrans (1999). Cycle Tourism, Information pack TT21. Bristol, UK: Sustrans.

Vesey, C., \& Dimanche, F. (2001). Urban Residents' Perceptions of Tourism \& Its Impacts: An Application of the TIAS Scale. In: Proceedings of the 32nd Travel \& Tourism Research Association Annual Conference 2001 (151-158). Fort Meyers, Florida: TTRA.

Vujko, A., \& Gajic, T. (2014). Opportunities for tourism development and cooperation in the region by improving the quality of tourism services-the 'Danube Cycle 
Route'case study. Economic research - Ekonomska istraživanja, 27(1), 847-860. doi: 10.1080/1331677X.2014.975517.

Vujko, A., Plavša, J., \& Ostojić, N. (2013). Impact of the "Danube cycling route" on the development of cycling tourism in Serbia. Polish Journal of Sport and Tourism, 20(3), 227-233.

Wang, Y., \& Pfister, R.E. (2008). Residents' attitudes toward tourism \& perceived personal benefits in a rural community. Journal of Travel Research, 47(1), 8493. doi: $10.1177 / 0047287507312402$

\section{СТАВОВИ ЛОКАЛНОГ СТАНОВНИШТВА О БИЦИКЛИСТИЧКОМ ТУРИЗМУ У ГОРЊЕМ ПОДУНАВЉУ (СРБИЈА)}

Вања Павлуковић, Бојана Никић, Угљеша Станков

Универзитет у Новом Саду, Природно-математички факултет, Нови Сад, Србија

\section{Резиме}

Бициклистички туризам је све значајнији облик туризма на европском туристичком тржишту, који у последње време привлачи пажњу како академске заједнице тако и творца туристичке политике на одређеној дестинацији. У нашој земљи је овај облик туризма препознат у стратешким документима као један од кључних туристичких производа које треба развијати у одабраним туристичким дестинацијама, а посебно у Подунављу. Дунавска бициклистичка рута, која је део једног од најатрактивнијих европских бициклистичких коридора Еуровело 6, најдужа је бициклистичка траса у Србији. Ипак, веома је мало истраживања на тему бициклистичког туризма, поготово у нашој земљи. За разлику од досадашњих истраживања, која се углавном баве туристима бициклистима, у средишту овог истраживања је локално становништво, које је један од кључних партнера у развоју било ког облика туризма на некој дестинацији.

У испитивању ставова локалног становништва о бициклистичком туризму примењена је ТИАС скала (енгл. Tourism Impact Attitude Scale - TIAS), која је до сада имала широку примену у туристичким истраживањима, углавном на тему руралног туризма. Оригинална скала је прилагођена облику туризма који се истражује, што предлажу и аутори саме скале. Истраживање је спроведено у периоду од јуна до септембра 2016. године техником „лице у лице” међу локалним становништвом у Горњем Подунављу у општинама Апатин, Сомбор и Бачка Паланка. Укупно је попуњено 109 упитника.

Резултати истраживања показују да је две трећине испитаника упознато са чињеницом да кроз њихову општину пролази Дунавска бициклистичка рута - Еуровело 6. Већина испитаника подржава развој бициклистичког туризма и то најчешће наводе као разлог јер су и сами љубитељи бициклизма, у туризму виде шансу за економски развој општине и за запошљавање локалног становништва, али и могућност побољшања инфраструктуре. Скоро 50\% испитаника не сматра да бициклистички туризам има битну улогу у привреди њихове општине, док $32 \%$ нема конкретан став по овом питању. Са друге стране, већина анкетираних сматра да општина треба плански да развија овај вид туризма и да њихово насеље има шансу да постане атрактивна дестинација бициклистичког туризма. На основу резултата истражи- 
вања, може се закључити да је бициклистички туризам неразвијен или бар у почетној фази развоја у општинама у којима је спроведено истраживање, те да потенцијали Дунавске бициклистичке руте нису искоришћени у Горњем Подунављу, али испитаници виде могуће позитивне ефекте од развоја овог облика туризма, те му стога пружају подршку.

У раду је извршено и тестирање утицаја пола, година старости, нивоа образовања и месечног прихода испитаника на ставове о бициклистичком туризму. Статистички значајне разлике утврђене су само у ставовима испитаника са различитим месечним примањима, и то свега код четири тврдње од двадесет и две тврдње.

Како локално становништво остварује директан контакт са туристима, од којег у великој мери зависи какав ће доживљај конкретни туриста понети са одређене дестинације, неопходно је информисати и едуковати локалну заједницу о могућностима и користима које развој бициклистичког туризма доноси, те подстаћи развој малих и средњих предузетника који би пружали различите услуге туристима бициклистима, по узору на примере добре праксе из европских земаља и посебно земаља у окружењу.

Будућа истраживања треба спровести у преостале три дестинације у Подунављу (Средње Подунавље, Град Београд са гравитационом зоном и Доње Подунавље) како би се утврдиле евентуалне разлике у ставовима локалног становништва о бициклистичком туризму. Истраживања оваквог типа треба континуирано спроводити јер се степен развијености туризма на дестинацији мења и, самим тим, мења се и перцепција локалне заједнице о ефектима туризма. 